\title{
EXERGY ANALYSIS OF PROCESSES OCCURING IN COOLING TOWER
}

\author{
O.A. Kardasevich, V.V. Chichenin, V.G. Ahrameev, N.V. Demchenko \\ Odessa National Polytechnic University, Odessa \\ e-mail: twf.onpu@gmail.com
}

\begin{abstract}
The paper discusses physico-chemical processes occurring during the interaction of water environment and air in cooling tower. As the results of exergy analysis of those processes, it was found that ratio of energy and exergy flows is associated with mass transfer and heat transfer. The effectiveness of exergy transformation in the cooling tower was evaluated. The mechanism for determining the exergy losses in the local processes of mass transfer, heat transfer and dissipative effects occurring in the cooling tower is proposed.
\end{abstract}

\section{Introduction}

As known, exergy analysis of technical objects allows more correctly to assess the effectiveness of the processes occurring in them, to identify ways to improve these processes, make them clear, compelling with a more accurate idea about the real possibilities of improvement in these conditions are more precisely tailored to the particular environment. However, for devices and processes that are directly related to interaction with the environment and this interaction is "depreciation" of energy into anergy, and the application of this method of analysis is not widely spread. In the paper an attempt is made to fill this gap, in order to obtain additional indicators that more fully illuminate the processes occurring in the cooling tower.

\section{Literature review}

A relatively new method of thermodynamic analysis of exergy [1-3], as evidenced by publications [4-8] remains an important direction of research in energy and heat engineering, as well as gaining a place in chemical technology and a number of other areas, including to evaluate the behavior of impurities in water coolers, such as cooling tower, there is formation of deposits on heating surfaces.

The advantage of exergy method in consideration of not only the quantity but also the quality of energy flow and multicomponent material flows, characterising the energy balance of any energy system that puts this method in the first place for its objectivity compared to traditional methods of thermodynamic analysis.

In $[4,6]$, the analysis of such processes requires taking into account not only the traditional power system the concept of exergy as a workable component of the reserves of energy heat and work [1], but the chemical component [4]. This complicates the calculations and preparation of balance sheets, the choice of criteria of efficiency of the division as a whole and the individual steps and parts of plants (steps), which are usually broken and difficult process. For the tower, as seen later, it is possible to simplify such an analysis, and despite the mass, confined to the clarification of the concept "environment", and exergy conversion processes of vaporization to characterize "hidden" exergy of vaporization, which is similar to the heat of vaporization. It is used as a synonym for "chemical" component. 


\section{Statement of the problem}

Cooling tower refers to devices with multi-component flows in which there are processes of water cooling, including evaporation and heat transfer. A portion of the water cooling tower when it turns to vapor, which leads to the concentration of the contained impurities in the remaining water. Even at low initial hardness of the water feeding, over time, in the process cooling tower, the stiffness will increase. Water with high value of stiffness will inevitably lead to the failure of most of the elements of the circuit, since the increase in the concentration of the impurities out of solution as solid particles, destructive acting on the circuit elements. With increasing stiffness the surfaces of the cooling tower very fast deposits form, which will eventually lead them to destruction. That's why there was a need to explore in more detail the processes occurring in the cooling tower (such as mass transfer and heat transfer), not only traditional approaches, but also to conduct exergy analysis of the cooling tower.

The complexity of this analysis lies in the fact that the main technical effect of the cooling process here is not clearly expressed, or more precisely cooling is by convective heat transfer, and mass transfer (evaporation) with the manifestation of the "latent" heat of evaporation, and education in water solid phase of impurities, And the problem arises how to characterize the exergy conversion in these processes, moreover, that the phase transition occurs at a varying temperature of the humid air, and, consequently, with variable partial vapor pressure in the humid air.

In addition, in the cooling tower heat rejection to the environment, leads to a complete depreciation of energy resources. And this is achieved in two quite different ways: as a result of heat transfer and mass transfer. In this paper, an attempt is made to find out which process dominates in cooling towers and how it relates to the environment, the concept of which is the base for the exergy analysis.

\section{Analysis of the cooling tower, comprising carrying out the exergy analysis of the processes occurring in it.}

In the work, along with the traditional approaches to the evaluation of the behavior of water in cooling systems, used the unit of thermodynamic analysis based on exergy. Recall that the concept of exergy was suggested by Z. Rant [3] in 1953 and its using has created a section of thermodynamics. Exergy, like energy, has the property of additivity, which simplifies the calculation of the exergy of complex systems and processes. Unlike energy, exergy is lost due to the occurrence of irreversible processes, or as say that in such processes the exergy is transformes into anergy. This property of exergy unites it with the cost and the money and creates the preconditions for the transition to thermoeconomical analysis of the processes and devices [1]. The greatest development and wide dissemination of the exergy method is found in the analysis of cycles and key processes of TPP and NPP. Therefore, in the paper borrowed the approaches developed there which reduces to the fact that for all stocks, flows and transformations of energy in specific environment conditions $\left(T_{0}, p_{0}\right)$ to calculate their exergy, i.e. the energy component, which capable of turning entirely to the work and any other type of energy[2]. In this regard, consider:

- the specific exergy $(\mathrm{kJ} / \mathrm{kg}$ ) mass flow of the medium (neglecting kinetic and piezometric component):

$$
e=\left(h-h_{0}\right)-T_{0}\left(s-s_{0}\right)
$$

- the exergy of the heat flow $(\mathrm{kW})$ 


$$
E_{q}=\Phi\left(1-\frac{T_{0}}{T}\right)
$$

where $\mathrm{h}$ and $\mathrm{h}_{0}$ are the enthalpy, respectively, in this state and the state of the environment, $\mathrm{kJ} / \mathrm{kg}$;

$\mathrm{s}$ and $\mathrm{s}_{0}$ are the entropy, respectively, in this state and the state of the environment in $\mathrm{kJ} /(\mathrm{kg} \cdot \mathrm{K})$;

$\mathrm{T}$ and $\mathrm{T}_{0}$ are the temperature, respectively, in this state and the state of the environment;

$\mathrm{F}$ - heat flux, $\mathrm{kW}$.

In the case of physical and chemical transformations there is a need to supplement the concept of environment and its parameters [1,2,4]. In relation to cooling towers, this additional parameter is the state in which exposed to ambient water vapor. Most convenient to use the concept of relative humidity (in shares or \%):

$$
\varphi=\rho_{\mathrm{p}} / \rho^{\prime \prime},
$$

where $\rho_{\mathrm{p}}$ is the density of vapor in air, $\mathrm{kg} / \mathrm{m}^{3}$;

$\rho^{\prime \prime}$ is the density of vapor in the air (at saturation) at the temperature $\mathrm{t}, \mathrm{kg} / \mathrm{m}^{3}$.

Then the relative humidity in the environment:

$$
\varphi_{0}=\rho_{\mathrm{p}} / \rho_{0} ",
$$

where $\rho_{\mathrm{p}}$ is the density of vapor in air, $\mathrm{kg} / \mathrm{m}^{3}$;

$\rho_{0}{ }^{\prime \prime}$ is the density of vapor (at saturation) at ambient temperature $\mathrm{T}_{0}, \mathrm{~kg} / \mathrm{m}^{3}$.

Equation (3) under the assumption that the water vapor in the air, because of the small partial pressures, obey the equation Clapeyron-Mendeleev may also be represented in the form

$$
\varphi=\mathrm{p}_{\mathrm{p}} / \mathrm{p}_{\mathrm{s}}
$$

where $\mathrm{p}_{\mathrm{p}}$ is the partial vapor pressure in air, $\mathrm{Pa}$ or $\mathrm{kPa}$;

$\mathrm{p}_{\mathrm{s}}$ - the maximum possible partial pressure of vapor in the air (at saturation) at air temperature $\mathrm{t}, \mathrm{kPa}$.

Then the partial pressure of water vapor in the environment will be true:

$$
\mathrm{p}_{\mathrm{p} 0}=\varphi_{0} \cdot \mathrm{p}_{\mathrm{s}}
$$

where $\mathrm{p}_{\mathrm{p} 0}$ is the partial pressure of water vapor in the environment, $\mathrm{Pa}$ or $\mathrm{kPa}$.

Therefore the list of environment parameters for the exergy calculations of the processes in the cooling tower is:

- the atmospheric pressure $\mathrm{p}_{0}$;

- the temperature of the air entering the cooling tower $\mathrm{T}_{0}, \mathrm{~K}$;

- partial pressure of water vapor in the environment, $\mathrm{p}_{\mathrm{p} 0}$ or an equivalent value $\varphi_{0}$.

In fig. 1 there is a diagram of the process of cooling the circulating water in the cooling tower power block.

When performing exergy analysis of the processes, the calculations begin with the raw data about the state of the environment. For example, in this work the analysis of cooling tower performance of the NPP and the initial data are taken information about the state of the atmosphere in summer, Rivne NPP. 
Therefore, in calculations it is accepted: $\mathrm{p}_{0}=100 \mathrm{kPa}$ or $1 \mathrm{bar}$;

$\mathrm{T}_{0}=273+\mathrm{t}_{\mathrm{v}}=273+18,7=291,7 \mathrm{~K}$, Rivne;

where $t_{v}=18,7^{\circ} \mathrm{C}-$ the average temperature in summer at the climate data for the city of

$\varphi_{0}=80 \%=0,80$ - adopted in the calculation of the value (at the climate data for this area the relative humidity may vary in the range from 60 to $95 \%$ ).

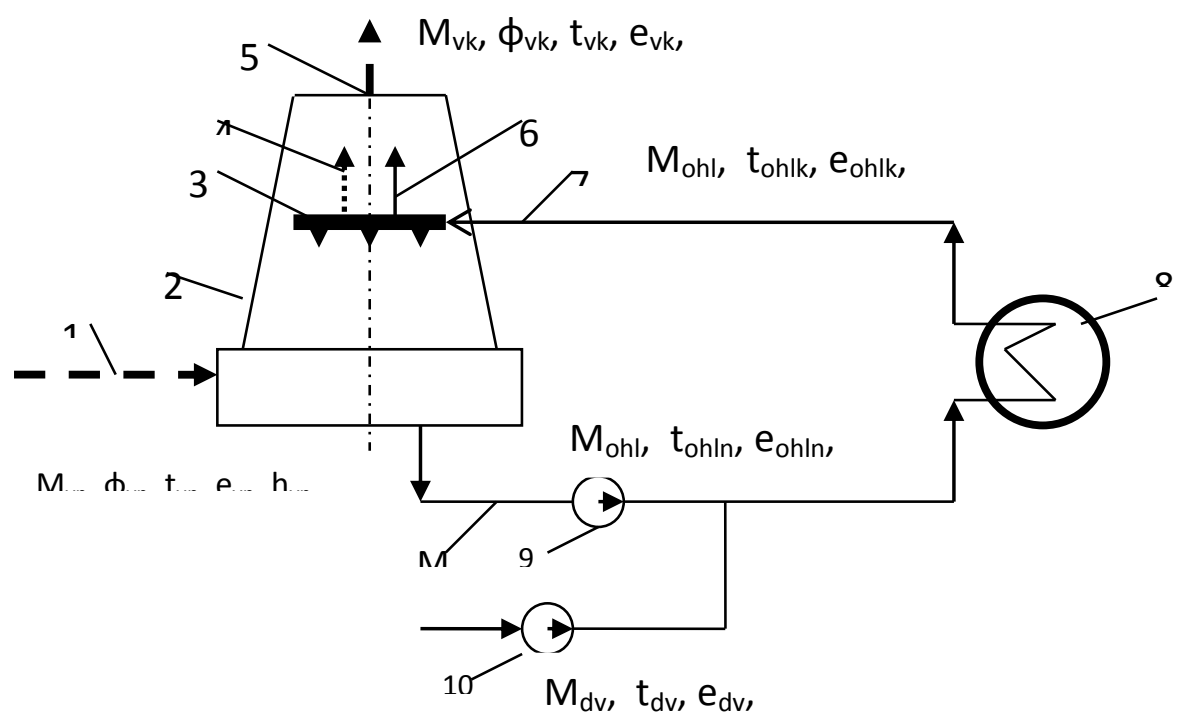

1 - the flow of air from the environment, 2 - tower, 3 - distributor, 4 - flash, 5 - exit of moist air, 6 - entrainment, 7 - supply of heated cooling water from condenser, 8 - condenser of the turbine, 9 - pump, 10 - charging pump

Fig.1. Diagram of the circulation cooling of the condensers of the power block with the cooling tower

These environment parameters will match the maximum possible partial pressure of vapor in the air (at saturation when the air temperature is $\mathrm{t}=18,70 \mathrm{C}$ ) $\mathrm{p}_{\mathrm{s}}=2,16 \mathrm{kPa}$ and the partial pressure of water vapor in the environment $\mathrm{p}_{\mathrm{p} 0}=\varphi_{0} \cdot \mathrm{p}_{\mathrm{s}}=0,80 \cdot 2,16=1,73 \mathrm{kPa}$. They correspond to another parameter, the moisture content of moist air:

$$
d=0,622 \frac{\varphi \cdot p_{s}}{p-\varphi \cdot p_{s}}
$$

For example, $\mathrm{d}_{0}=0,0109 \mathrm{~kg} / \mathrm{kg}$ or $\mathrm{d} 0=10,9 \mathrm{~g} / \mathrm{kg}$ (grams of vapor per $1 \mathrm{~kg}$ of dry air).

These values of the parameters characterizing the state of the environment, is used as the possible variants of the basic parameters for the calculation of the specific exergy of all flows including wet air [5] for the different sections of the tower. In particular, the parameter $\mathrm{p}_{\mathrm{p} 0}$ is used to calculate the exergy of steam in the humid air, as part of the moist air. However, the exergy of moist air can be represented as the arithmetic sum of independent flows of exergy of dry air and vapor only formally due to the fact that moist air is a mixture of dry air and steam, and any mixing is always accompanied by increase of entropy and losses of exergy. Therefore, the amount of exergy air and steam do not always fully reflect the exergy wet steam. Exergy of moist air as a 
function of three variables $(\mathrm{p}, \mathrm{t}, \varphi)$ can be calculated based on the specified parameters [5], or found by the Bes's nomogram for the exergy of moist air. The paper analyzes the possibility of calculations for different choices of the parameters of the environment. Moreover, it was found that the processes in the cooling tower flow in a region very close to the state of the environment in connection with what is very low the accuracy of the calculations, particularly for the entropy. The most significant error in finding the specific exergy of the nomogram "exergy - moisture content".

The study first considers the cooling tower as a "black box", restricting the flow only at the border, and determined only the total loss of exergy, and therefore received very little data for the analysis of energy transformations in the cooling tower. That's why, along with this approach to determine the distribution of losses of exergy in some of the most important local processes, it is proposed to introduce the concept of a "dummy" (seemingly) heat fluxes of each component of moist air. Otherwise: the overall process of energy transfer from cooling water to the humid air is represented as a set of parallel local processes: heat transfer of the heated dry air in the cooling tower; heat transfer heating of the part of moisture that is in the original flow of moist air, and moist air at the exit - even heat transfer of that part of the moisture, which evaporated and went into the humid air. The exergy of these components is calculated from equation (2) according to the calculated heat flows. In this case, these components will be a function of pressure and same temperature - the average temperature of the moist air in the cooling tower, therefore the amount of exergy of the air inlet and will represent the exergy of the humid air at the outlet of the cooling tower. The most important increment of the exergy of evaporated moisture in the air is called exergy "evaporation" to reflect the fact that the process of energy transfer in cooling towers is due to mass transfer and is carried out by evaporation of the moisture. Exergy evaporation is a complete analogue of the chemical exergy [7,8]. For all these flows of exergy, found in "fake heat", quite rightly, the rule of additivity, used for both flows of exergy due to heat transfer with dry air and entrained moisture and exergy evaporation. The exergy of moist air at the exit of the cooling tower is considered as drip loss.

For analysis and comparison, along with specific exergies, defined as the complete flow of exergy for each component of the single-phase environment (dry air, steam-air, water, and "the entrainment of moisture" (moisture droplets) according to their costs.

The implementation of exergy analysis is always preceded by a determination of the costs and parameters of all flows characteristic of the cooling tower. The list and designations are given in fig.1.

The task of defining the parameters associated with the material balances and concentrations of moisture in the original air flow and at the end of the process illustrated in $\mathrm{H}$ - $\mathrm{d}$ diagram, which allows to determine the partial pressure of vapor in the air, necessary for the calculation and balancing of the flows of exergy.

In the subsequent example calculations used experimental data for the cooling tower with cross-sectional area $\mathrm{S}=4000 \mathrm{~m}^{2}$, with a density of irrigation $v_{o r}=5,6 \mathrm{~m}^{3} /\left(\mathrm{m}^{2} \cdot \mathrm{h}\right)$; mediolateral water in the cooling tower $\theta_{\mathrm{gr}}=6^{0} \mathrm{C}$. For condensers of the turbine made the pressure in the condenser $p_{k}$ $=5 \mathrm{kPa}$, enthalpy of steam inlet to the condenser $\mathrm{h}_{2}=2307 \mathrm{~kJ} / \mathrm{kg}$ enthalpy of condensate generated condensate $\mathrm{h}_{\mathrm{k}}^{\prime}=121,4 \mathrm{~kJ} / \mathrm{kg}$.

The flow rate of the cooling water entering the cooling tower is found by the equation of continuity and the value of the heating water in the condenser via the circulating ratio of water.

Water temperature at the outlet of the cooling tower and entering the condenser associated with not enough chilled water in the cooling tower is determined by the patterns of heat and mass transfer in cooling towers, which are not considered here. Therefore, they are determined by the value of underheating $\theta_{\mathrm{gr}}=6^{0} \mathrm{C}$, taken from experimental data. 
Mixing the flow of circulating water with extra water consumption which is determined by the water losses in the cooling tower due to evaporation and entrainment of moisture, it has been possible to neglect taking into account a small percentage of this flow and a slight decrease in the temperature of the circulating water after mixing, offset by additional increase in temperature due to compression in the pump, $\mathrm{t}_{\text {ohln }} \approx \mathrm{t}_{2 \mathrm{gr}}$.

This simplification allows us to calculate the temperature of the cooling water for the condenser, assuming that the cooling tower is implemented by an ideal countercurrent flow, the temperature of the air exiting the cooling tower, $\mathrm{t}_{\mathrm{vk}}$ :

Since the flow of air exiting the cooling tower is saturated with water vapor, then the temperature $t_{v k}$ found the partial pressure of water vapor in moist air $\left(\mathrm{p}_{\mathrm{vk}}\right)$ and then the moisture content via (7).

The specific quantity of the vapor evaporating, rolling in the cooling tower into the air $(\Delta d=$ $\mathrm{d}_{2}-\mathrm{d}_{\mathrm{n}}$ ), calculates an appropriate flow of evaporating vapor.

The air flow through the cooling tower depends on the intensity of heat and mass transfer in cooling tower (a crucial parameter for these processes is the velocity of air that is in the range $0,5 \ldots 1,2 \mathrm{~m} / \mathrm{s}$ ) and energy balance of the cooling tower. The complexity of the descriptions of the relationships of these processes requires a method of successive approximations in the solution of a problem of determination of air flow

The adopted algorithm is the following:

First, we calculated the flow of evaporated water $\mathrm{m}_{\mathrm{isp}}$ simplified energy balance of the cooling tower in order to find the flow rate of dry air, and then specified the rest of the flow, including air flow according to the revised energy balance. We compared the results and through iterations we determined the costs to errors of less than one percent, and at the same time was tested is the velocity of air in the cooling tower within the specified limits. You need to keep in mind that at higher speeds, increasing the likelihood of entrainment of water droplets.

For example, found the proportion of evaporated water in $\% \alpha_{\text {isp }}=1,43$, as well as air speed: $\mathrm{W}_{\mathrm{v}}=1,11 \mathrm{~m} / \mathrm{s}$, which is in the acceptable range.

The amount of entrainment from a cooling tower is adopted at $0,5 \%$, using statistical data. Note that the main influence on the entrainment is having the presence or absence of drift eliminators and their effectiveness, as well as air speed. Additionally, the analysis shows that the removal of the water with the air flow comparable with the amount of evaporated moisture is less, and only a few times, but the magnitude of their energy flows, as shown, differ by 2 orders of magnitude.

\section{Energy flows in the cooling tower}

Energy flows in the cooling tower are determined by the amount of energy and material flows and their parameters, as well as energy balances. We determined: the stream enthalpy of the water at the outlet of the cooling tower, $\mathrm{H}_{\mathrm{gr} 2}$; stream enthalpy of the water entering the condenser in a given mixing $\mathrm{H}_{\mathrm{k} 1}$; streams the enthalpy of water at the outlet of the condenser (at the entrance to the tower), $\mathrm{H}_{\text {ohlk }}$; with ablation of condensed moisture $\mathrm{H}_{\mathrm{un}}$.

The flow of enthalpy of air at inlet and outlet of the cooling tower calculated according to the rule of additively as the sum of the enthalpies of dry air and moisture (steam) contained therein. The calculated specific enthalpy of moist air is related to $1 \mathrm{~kg}$ dry air compared with a specific enthalpy of moist air, defined by the so-called " $h$ - d" Ramzin's diagram. The results are comparable, but indicate a significant error of using the chart. However, visibility, which are the processes in this diagram are very useful, and will use in the future. 
Is important to analyze not the absolute flows and their relative values $\mu_{\mathrm{i}}=\mathrm{H}_{\mathrm{i}} / \mathrm{H}_{\mathrm{Bx}}$ and $\mu_{\mathrm{i}}=$ $\mathrm{H}_{\mathrm{i}} / \mathrm{H}_{\max }$ where $\mathrm{H}_{\mathrm{vh}}$ energy flow of water at the entrance, $\mathrm{H}_{\max }=\mathrm{H}_{\mathrm{vh}}+\mathrm{H}_{\mathrm{sv}}+\mathrm{H}_{\mathrm{pn}}$ is the total energy flow at the entrance to the tower.

The results of calculations of energy flows and their relative distribution throw mediums $\left(\mu_{\mathrm{i}}=\right.$ $\left.\mathrm{H}_{\mathrm{i}} / \mathrm{H}_{\mathrm{vh}}, \mu_{\mathrm{i}}=\mathrm{H}_{\mathrm{i}} / \mathrm{H}_{\max }\right)$ are given in table. 1 .

From table 1 we can conclude that a useful result, to ensure the cooling water in the cooling tower mainly by evaporation (energy resources $\mathrm{H}_{\mathrm{d} 2}$ ), the relative share of which is in the wet steam at the outlet of the cooling tower is: $\mu_{\mathrm{d} 2}=\mathrm{H}_{\mathrm{d} 2} / \mathrm{H}_{\mathrm{vh}}=0,321$, and the proportion of energy associated with the heated dry air: $\mu_{\mathrm{vk}}=\mathrm{H}_{\mathrm{vk}} / \mathrm{H}_{\mathrm{vh}}=0,142$.

To evaluate the ratio between the energy going into evaporation and heating of moist air, was found further energy source that is associated with increasing energy (heat) that part of the moisture $\left(\mathrm{d}_{1}\right)$, which enters the cooling tower with air: $\Delta \mathrm{H}_{\mathrm{d} 1}=\mathrm{m}_{\mathrm{sv}} \mathrm{d}_{1}\left(\mathrm{~h}_{\mathrm{d} 1 \mathrm{k}}-\mathrm{h}_{\mathrm{d} 1 \mathrm{n}}\right)$ and determined the ratio of energy going on heating and evaporation:

$$
\alpha_{\mathrm{t} / \mathrm{o}}=\Delta \mathrm{H}_{\mathrm{d} 1} /\left(\mathrm{H}_{\mathrm{pk}}-\Delta \mathrm{H}_{\mathrm{d} 1}\right)
$$

For example, $\alpha_{\mathrm{t} / \mathrm{o}}=0,392$.

Such insights may come, if we use the h-d diagram of moist air and plot of process air in the cooling tower. The decision, made on a large-scale h-d graph for the ratio of heat flow, given that

The result is very close to that calculated earlier (8). The variance explained is not high accuracy of obtaining the segments in $\mathrm{h}$ - $\mathrm{d}$ diagram.

Energy and material flows in the cooling tower

Table 1

\begin{tabular}{|c|c|c|c|c|c|c|c|c|}
\hline $\begin{array}{l}\text { Para- } \\
\text { meter }\end{array}$ & $\begin{array}{l}\text { Water } \\
\text { entering } \\
\text { the } \\
\text { cooling } \\
\text { tower }\end{array}$ & $\begin{array}{c}\text { The } \\
\text { water at } \\
\text { the outlet } \\
\text { of the } \\
\text { cooling } \\
\text { tower }\end{array}$ & $\begin{array}{l}\text { Dry air } \\
\text { entering } \\
\text { the } \\
\text { cooling } \\
\text { tower }\end{array}$ & $\begin{array}{l}\text { Dry air at } \\
\text { the outlet } \\
\text { of the } \\
\text { cooling } \\
\text { tower }\end{array}$ & $\begin{array}{l}\text { Mois- } \\
\text { ture } \\
\text { (vapor) } \\
\text { in the } \\
\text { air } \\
\text { entering } \\
\text { the } \\
\text { cooling } \\
\text { tower }\end{array}$ & $\begin{array}{l}\text { Moisture } \\
\text { (vapor) in } \\
\text { the air at } \\
\text { the outlet } \\
\text { of the } \\
\text { cooling } \\
\text { tower }\end{array}$ & $\begin{array}{l}\text { The } \\
\text { entrain } \\
\text { ment of } \\
\text { moisture } \\
\text { from the } \\
\text { cooling } \\
\text { towers }\end{array}$ & $\begin{array}{l}\text { The } \\
\text { conver- } \\
\text { sion of } \\
\text { energy }\end{array}$ \\
\hline $\begin{array}{c}\text { Energy } \\
\text { flow,M } \\
\text { W } \\
\end{array}$ & 919 & 632,3 & 107,7 & 168,2 & 158,3 & 380,5 & 3,81 & $\begin{array}{c}\mathrm{H}_{\mathrm{pol}}=20 \\
7,4\end{array}$ \\
\hline $\begin{array}{c}\text { The } \\
\text { specific } \\
\text { flow of } \\
\text { energy, } \\
\mathrm{H} / \mathrm{H}_{\max } \\
\text { и } \mathrm{H} / \mathrm{H}_{\mathrm{vk}}\end{array}$ & $\begin{array}{c}1,0 \\
0,775\end{array}$ & $\begin{array}{l}0,688 \\
0,534\end{array}$ & $\begin{array}{l}0,117 \\
0,091\end{array}$ & $\begin{array}{l}0,183 \\
0,142\end{array}$ & $\begin{array}{l}0,172 \\
0,134\end{array}$ & $\begin{array}{l}0,414 \\
0,321\end{array}$ & $\begin{array}{l}0,004 \\
0,003\end{array}$ & - \\
\hline $\begin{array}{c}\text { The } \\
\text { mass } \\
\text { flow, } \\
\mathrm{kg} / \mathrm{s}\end{array}$ & $6,22 \cdot 10^{3}$ & 6103 & $5,73 \cdot 10^{3}$ & $5,73 \cdot 10^{3}$ & 62,5 & 149 & 31,1 & $\begin{aligned} & m_{i s p} \\
= & 86,2\end{aligned}$ \\
\hline
\end{tabular}


Found energy and material flows of media in the cooling tower allow to calculate and to make the balance of exergy loss and exergy, as well as to more fully analyze the processes of energy transformation in the cooling tower.

The calculation of the specific flows exergy environments, as already noted, involves determining, in addition to the specific enthalpy and specific entropy flows. Including relevant environment conditions. Earlier it was explained that equivalent here can be a few options.

The paper considers the variant in which environment and for dry air and for water and water vapor is characterized by the parameters $\mathrm{r}_{0}$ and $\mathrm{t}_{0}$, and for example, calculations of the selected parameters $\mathrm{p}_{0}=100 \mathrm{kPa}$ and $\mathrm{T}_{0}=291,7 \mathrm{~K}\left(\mathrm{t}_{0}=18,7{ }^{0} \mathrm{C}\right)$.

With this approach, for flow of water (cooling, circulating and the entrainment) specific enthalpy and specific entropy in all states are defined by tables of properties of water and steam. In particular, for example: $\mathrm{h}_{0}=\mathrm{f}\left(\mathrm{p}_{0}, \mathrm{t}_{0}\right)=78,5 \mathrm{~kJ} / \mathrm{kg}$ и $\mathrm{s}_{0}=\mathrm{f}\left(\mathrm{p}_{0}, \mathrm{t}_{0}\right)=0,2779 \mathrm{~kJ} /(\mathrm{kg} \cdot \mathrm{K})$, and for flow of dry air, these parameters are calculated, which is more convenient, using the concept of heat capacity at constant pressure: $\mathrm{h}_{0 \mathrm{sv}}=18,7 \mathrm{~kJ} / \mathrm{kg}$ and $\mathrm{s}_{0 \mathrm{sv}}=0,0662 \mathrm{~kJ} /(\mathrm{kg} \cdot \mathrm{K})$.

It should be noted that all calculations associated with the calculation of the specific exergy are very small resulting values of difference values. Therefore, their reliability is small, and the error is significant. However, they can be used for analysis and for ease of analysis we reduce these data in table. 2 , which shows also the relative importance of these flows in relation to the flow exergy at the inlet.

Found the flow exergy were used to calculate for the tower in General, the total exergy losses: $\mathrm{P}=$ Evh - Evih (for example, $\mathrm{P}=9,20 \mathrm{MW}$ ).

Made the balance of exergy for water and air under selected environmental parameters $\mathrm{r} 0$ and t0 indicates a very large "transit" component of the flows of exergy, so it makes sense to consider and evaluate energy transformation (increment or decrease) of exergy for separate environments that more accurately reflect energy conversion, and the amount of loss of these values can be considered as available exergy, $\Delta \mathrm{E}_{\text {ras }}$ and the increment of exergy as used exergy, $\Delta \mathrm{E}_{\text {isp.. }}$

Exergy flows in separate flows of media in the cooling tower

Table 2

\begin{tabular}{|c|c|c|c|c|c|c|c|}
\hline Parameter & $\begin{array}{c}\text { Water } \\
\text { entering the } \\
\text { cooling } \\
\text { tower } \\
\text { at the } \\
\text { outlet of } \\
\text { the cooling } \\
\text { tower }\end{array}$ & $\begin{array}{c}\text { The water } \\
\text { entering } \\
\text { the cooling } \\
\text { tower }\end{array}$ & $\begin{array}{c}\text { Dry air at } \\
\text { the outlet } \\
\text { of the } \\
\text { cooling } \\
\text { tower }\end{array}$ & $\begin{array}{c}\text { Moisture } \\
\text { (vapor) in } \\
\text { the air } \\
\text { entering } \\
\text { the } \\
\text { cooling } \\
\text { tower }\end{array}$ & $\begin{array}{c}\text { Moisture } \\
\text { (vapor) in } \\
\text { the air at } \\
\text { the outlet } \\
\text { of the } \\
\text { cooling } \\
\text { tower }\end{array}$ & $\begin{array}{c}\text { The } \\
\text { entrainme } \\
\text { nt of } \\
\text { moisture } \\
\text { from the } \\
\text { cooling } \\
\text { towers }\end{array}$ \\
\hline $\begin{array}{c}\text { The flow } \\
\text { of exergy, } \\
\text { MW }\end{array}$ & 15,24 & 3,56 & 102,5 & 93,4 & 1,25 & 12,8 & 0,027 \\
\hline $\begin{array}{c}\text { The } \\
\text { relative } \\
\text { flow of } \\
\text { exergy, } \\
\text { E/Ek }\end{array}$ & 0,13 & 0,030 & 0,857 & 0,785 & 0,066 & 0,108 & 0,005 \\
\hline
\end{tabular}

This approach will not affect the estimate of the total loss of exergy, which is now expressed as the difference between disposable and used exergue $\mathrm{P}=\Delta \mathrm{E}_{\mathrm{ras}}-\Delta \mathrm{E}_{\text {isp. }}$. 
It is important to emphasize that the source of exergy serves as a cooling water and the air, picking up from the environment. Note that large values of transit flows of exergy reflect the separate choice of the basic parameters for water and air. Attempt to link the underlying, the zero counts of exergy and to consider moist air as a whole not only material flow, but also as a single stream of exergy, performed, as already mentioned, Bes [5], who developed, in analogy with the $\mathrm{h}-$ $\mathrm{d}$ chart, the chart allows you to graphically determine the specific exergy of humid air is related to $\mathrm{kg}$ of moist air. The use the Bes's nomograms [5] allowed to obtain the specific exergy of humid air, related to $\mathrm{kg}$ of moist air, and then thread ispolzovanii of exergy in the cooling tower, the numerical value is close to previously found. The variance reflects the exergy losses caused by mixing flows of dry air and steam, and the fact that the Bes's nomogram designed for a very wide range of parameters, especially temperatures $(-300 \mathrm{C}$ to $+4600 \mathrm{C})$. This dramatically reduces the reliability and accuracy of results for a very narrow range of temperatures occurring in the cooling tower, so the Bes's nomogram for cooling towers is not very convenient and can hardly be recommended for use with full exergy analysis of cooling towers.

A more detailed analysis of the loss of exergy of the list and the main reasons for the work done, considering the heat exchange between two media: the heating (conventionally water) and heated (conventionally air). At the same time, heat flows divided by the evaporation process, the heating of dry air and heat that part of the steam which is the source of atmospheric air.

Exergy of each stream is calculated by (2) the exergy transferred as heat at the temperature level of the circulating water (available exergy) and the exergy of the air flow and its components (the exergy). The perceived exergy flows can be considered as the maximum possible increase of the exergy of the humidified air through heat exchange as a result of interaction environments.

This approach is therefore limited to immediately have used exergy, and does not consider input and output flows of exergy. There is an opportunity to evaluate the exergy losses for each of the local processes, and along with the losses of exergy that are associated with transport and dissipation.

Data about the flows of exergy and exergy losses and the equity participation of each stream is listed in table. 3, and also graphically represented in Fig.2.

It should be noted that the flow of steam (moisture source air) passes through the cooling tower, which is entered along with the air, and it is characterized by heat exchange with a slightly different interpretation than the other local processes. The reason is that the steam flow is not only heated, but also increases its pressure, i.e. a phenomenon which is not typical for traditional heat transfer.

A comparison of the relative energy flows and their analogues in the flows of exergy (table.2, 3 and Fig. 2) indicate significantly different distributions in the flows of energy and exergy. This particularly applies to water flow.

The total flow exergy, which is called the exergy used, only the potential to be used as cooling tower it is almost completely transformed into anergy the dispersion in the environment (air). However, to assess the thermodynamic efficiency of transformation in the cooling tower it is possible to form a dimensionless index that reflects the efficiency of conversion of exergy in the cooling towers, and may be called exergy efficiency 


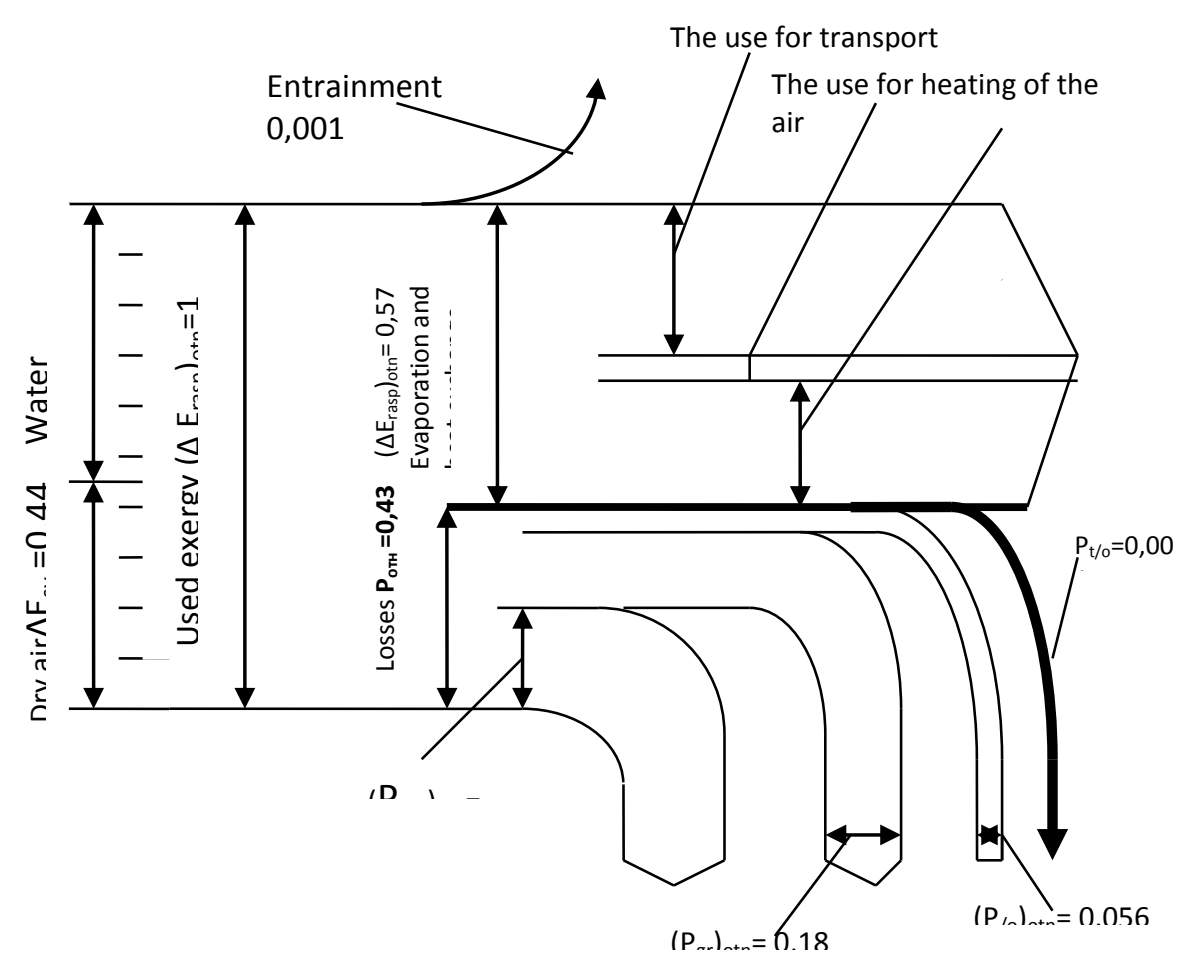

Fig.2. Flows of available and used exergy, and local losses of exergy in shares.

Available and used exergy (useful) in the cooling tower

Table 3

\begin{tabular}{|c|c|c|c|c|c|}
\hline Parameter & Totally & $\begin{array}{c}\text { During } \\
\text { evaporation }\end{array}$ & For air heating & $\begin{array}{c}\text { For moisture } \\
\text { heating } \mathrm{d}_{1} .\end{array}$ & $\begin{array}{c}\text { For transport } \\
\text { and etc. }\end{array}$ \\
\hline $\begin{array}{c}\text { Available exergy } \\
\text { MW }\end{array}$ & 20,78 & 7,92 & 2,24 & 0,043 & 10,58 \\
\hline $\begin{array}{c}\text { The specific flow } \\
\text { available exergy, } \\
\text { E/E }\end{array}$ & 1 & 0,38 & 0,11 & 0,002 & 0,51 \\
\hline Used exergy, MW & 11,58 & 3,70 & 1,07 & 0,021 & 6,79 \\
\hline $\begin{array}{c}\text { The specific flow } \\
\text { used exergy, E/E }\end{array}$ & 0,57 & 0,18 & 0,05 & 0,001 & 0,33 \\
\hline Exergy losses , MW & 9,02 & 4,22 & 1,17 & 0,022 & 3,79 \\
\hline $\begin{array}{c}\text { The specific exergy } \\
\text { losses P/E }\end{array}$ & 0,43 & 0,20 & 0,056 & 0.001 & 0,18 \\
\hline
\end{tabular}

If we accept that the useful exergy for the cooling tower is a flow increment of the exergy of evaporated water and the dry heated air and vapor to atmospheric air $\left(\Delta \mathrm{E}_{\text {pod }}\right)$, and have exergy $\Delta \mathrm{E}$ ras races is the loss of exergy interactive streams, the exergy efficiency can be written in the form:

$$
\eta_{\mathrm{ex}}=\Delta \mathrm{E}_{\mathrm{pod}} / \Delta \mathrm{E}_{\text {ras }},
$$

Or for the given variant of calculations: $\eta_{\mathrm{ex}}=0,23(23 \%)$. 
These results allow us to conclude that a significant portion of the exergy is not used in the cooling tower and either lost or are in transit. In principle this transit flow exergy can be used in the future, especially the thermal component, for example, dispose of it with the help of special devices. The analysis shows that the main losses of exergy are lost in the process of evaporation, in the process of heating dry air, and also in the transport and accompanying of dissipate in the mass transfer and the flow.

\title{
Conclusions
}

The analysis confirms the known fact about the prevailing role of evaporation of water in cooling towers technology from the point of view of energy balances, and exergy balance

The process of water evaporation in the cooling tower leads to the concentration of impurities in the remaining water, which negatively affects the circuit elements, and the need to remove a part of the circulating water, and with it the impurities. Such a process is accompanied with exergy losses and requires further study.

The way of radical improvement of cooling towers associated with the use of hybrid technology in which, simultaneously with the primary useful effect is cooling water, also used the potential of the moist air exiting the cooling tower, for example, in recuperarse fan devices.

\section{ЕКСЕРГЕТИЧНОЇ АНАЛІЗ ПРОЦЕСІВ, ЩО ПРОТІКАЮТЬ В ГРАДИРНІ}

\author{
О.А. Карадасевіч, В.В.Чіченін, В.Г. Ахрамеєв, Н.В. Демченко \\ Одеський національний політехнічний університет \\ e-mail: twf.onpu@gmail.com
}

В роботі розглянуті фізико-хімічні прочеси, щзо проходять при взаємодії водної середи та атмосферного повітря в градирнях, та викладено результати ексергетичного аналізу прочесів що проходять в них. 3'ясовано співвідношення енергетичних $і$ ексергетичних потоків, пов'язаних з масообміном $i$ теплообміном. Виконано оцінку ефективності перетворень ексергії в градирні. Запропоновано механізм визначення втрат ексергії в локальних процесах масообміну, теплообміну $і$ дисипативних проявів, щуо мають місце в градирні.

\section{ЭКСЕРГЕТИЧЕСКИЙ АНАЛИЗ ПРОЦЕССОВ, ПРОТЕКАЮЩИХ В ГРАДИРНЯХ}

\section{О.А. Карадасевич, В.В.Чиченин, В.Г. Ахрамеев, Н.В. Демченко}

Одесский национальный политехнический университет

e-mail: twf.onpu@gmail.com

В работе рассмотрены физико-химические процессы, протекающие при взаимодействии водной среды и атмосферного воздуха в градирнях, изложены результать эксергетического анализа прочессов протекающих в них Выяснено соотношение энергетических и эксергетических потоков, связанных с массообменом и теплообменом. 
Выполнена оченка эффективности преобразований эксергии в градирне. Предложен механизм определения потерь эксергии в локальных процессах массообмена, теплообмена $u$ диссипативных проявлений, имеющих место в градирне.

\section{References}

1. Kazakov V. G., Lukanin P. V., Smirnova O. S. Eksergeticheskie metodyi otsenki effektivnosti teplotehnologicheskih ustanovok. - SPb.: Sankt-Peterburg. gos. tehnol. un-t rastitelnyih polimerov, 2013. - $63 \mathrm{~s}$. - ISBN 978-5-91646-051-3.

2. Baehr H.D., Kabelac S.: Thermodynamik. Grundlagen und technische Anwendungen. 13., neu bearbeitete und erweiterte Auflage. Springer, Berlin u. a. 2006, ISBN 3-540-32513-1 (SpringerLehrbuch).

3. Müller A., Kranzl L., Tuominen P., Boelman E., Molinari M., Entrop A.G.: Estimating exergy prices for energy carriers in heating systems: Country analyses of exergy substitution with capital expenditures. Energy and Buildings, Volume 43, Issue 12, December 2011, Pages 36093617.Z. Rant. Forsch.Ing.Wes.,22, 36, (1956)

4. Szargut J.: Exergy Method. Technical and Ecological Applications. WIT Press, Southampton u. a. 2005, ISBN 1-85312-753-1 (Developments in heat transfer 18).

5. Szargut J. "Towards an International Reference Environment of Chemical Exergy"(PDF). Retrieved 15 April 2012.

6. Kardasevich O.O., Chichenin V.V., Hrytsayenko A.S. Exergy balance and efficiency of the example of deaerator. Odes'kyi Politechnichnyi Universytet. Pratsi, Issue 1(48), 2016

8. Rivero R.; Garfias M. (1 December 2006). "Standard chemical exergy of elements updated". Energy. 31 (15): 3310-3326. doi:10.1016/j.energy.2006.03.020.

УДК 621.187, 621.131 